\title{
Experimental Study on Compound Swirl jet
}

\author{
正 野绽 勉（鹿児島大） ○学 落合 崇（鹿児島大院） \\ 正 福原 稔（鹿児島大）
}

Tsutomu NOZAKI, Kagoshima University, 21-40 Koorimoto Ichome, Kagoshima

Takashi OCHIAI, Graduate School of Engineering, Kagoshima University, Minoru FUKUHARA, Kagoshima University

Key Words: Swirl flow, Entrainment, Push-pull type ventilator, Smoke method

\section{1. 緒詥}

各種室内の効果的排気を行うために，吸込みと吹出しを 組み合わせたプッシュ・プル換気方式が考えられている (1)(2). 円形自由噴流と環状旋回噴流からなる同軸噴流、い わゆる複合旋回噴流は,プッシュプル型換気装置のプッシ ュ気流に適した, 噴流半径の拡散が小さく, かつエントレ インメントの大きいつまりは周囲流体を巻き込む力が強い 噴流を得ることができている(3)(4)(5)(6).このことから，プッ シュプル型換気装置のプッシュ気流として複合旋回噴流を 用いることで，従来の自由噴流を用いた場合に比べ，その 高い巻き込み力からより効果的な污染物質の補足及び排気 が可能であるといえる.しかし，これまでの複合旋回噴流 はそれを創生する円形自由噴流と環状旋回噴流の空気源が それぞれコンプレッサー，送風機と別々になっているとい う問題があった。システムの実用化を考虑した場合，装置 のさらなるコンパクト化およびコスト削減の点から空気源 を一つで補うシステムへの変換が望まれる.

本研究では, 騒音・振動の面から室内で使うには適さな い円形自由噴流側のコンプレッサーを送風機に変換するこ とで，1 システム 1 ブロア化することを目指した．これに 伴い, 複合旋回噴流発生装置の幾何形状を見直し, 円形自 由噴流管内径を以前より大きくした. 装置改良後の複合旋 回噴流の特性を把握するために，基礎実験として流れの可 視化実験および 5 孔球形ピトー管による 3 次元速度分布測 定を行った.

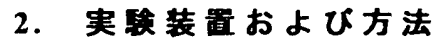

Fig. 1 に複合旋回噴流発生装置と座標系を示す。水平に 設置された複合旋回噴流ノズルの主要寸法は環状旋回噴流 口外側径 $D_{s o}=100 \mathrm{~mm}$, 環状旋回噴流口内側径 $D_{s r}=48 \mathrm{~mm}$, 自由噴流管内径 $D_{\digamma}=10 \mathrm{~mm}$, リ厶厚さ $T_{\digamma}=22 \mathrm{~mm}$, 助走長 さ $L_{a}=150 \mathrm{~mm}$, 案内羽長さ $L_{g}=60 \mathrm{~mm}$ およびスリット幅 $b=4 \mathrm{~mm}$ とした。 ここで,これまで複合旋回噴流発生装置 において，環状旋回噴流口外側径が $100 \mathrm{~mm}$ 嵅あるのに対 し, 円形自由噴流管内径を $4 \mathrm{~mm}$ と非常に小さくし, 高压 で吹出すことで高い流速を得ていた. よって, 空気源とし て高圧のコンプレッサーを用いていた.これを一般に中圧, 中流量の送風機に変換するにあたり, 自由噴流管内径 $D_{j}$
を $4 \mathrm{~mm}$ から $10 \mathrm{~mm}$ に改善した。

次に座標は円筒座標系を用い, 出口端の中心を原点とし, 噴流中心軸上下流方向に $\boldsymbol{z}$ 軸, 半径方向に $\boldsymbol{r}$ 軸をとる. 可 視化には，レーザーライトシート(LLS)を使用し，その光 源としてダブルパルス Nd:YAGレーザ(出力: $15 \mathrm{~mJ} / \mathrm{pulse}$, ビーム径: $2.5 \mathrm{~mm}$ )を用い, シリンドリカルレンズにより厚 さ約 $5 \mathrm{~mm}$ のシート状にして测定断面に間欠照射した。画 像取得には，デジタルビデオカメラを可視化断面に垂直に 設置し，撮影を行った．また, 5 孔球形ピト一管を用いて流 速測定を行ったが, その测定法の詳細については省略する.

本研究において

$$
S w=\frac{2 \pi \rho \int_{0}^{\infty} U_{z} U_{\theta} r^{2} d r}{2 \pi \rho \frac{D}{2} \int_{0}^{\infty} U_{z}^{2} r d r}
$$

で定義されるスワール数を用いて旋回の強さを表し(7)、本 実験では, 1.50 一定とした。また、複合旋回噴流発生装置 の幾何形状は一定とし, 力学的条件として, プッシュ側流 れとして適した条件(4)(5)である流量比 $Q_{s} / Q_{j}$ が 1.0 の複合旋 回噴流で実験を行った。ここで, 円形自由噴流流量 $Q_{j}$ は $4.5 \times 10^{-3} \mathrm{~m}^{3} / \mathrm{sec}$ とした。

3 次元速度分布测定については, 管出口端からの距離 $z$ を 環状旋回噴流口外側径 $D_{s o}$ で無次元化した下流位置 $2 / D_{s o}$ を 0.5 から 5 まで 0.5 おきに 10 断面の測定を行った. そし て $z$ 軸を含む垂直面 $(r-z$ 面)内で, $z$ 軸から垂直方向 $(r$ 方 向) 5 孔球形ピトー管をトラバースさせ測定を行った.な お, 吹出し口付近では $5 \mathrm{~mm}$, 下流では 10 から $15 \mathrm{~mm}$ 間 隔でトラバースさせた。

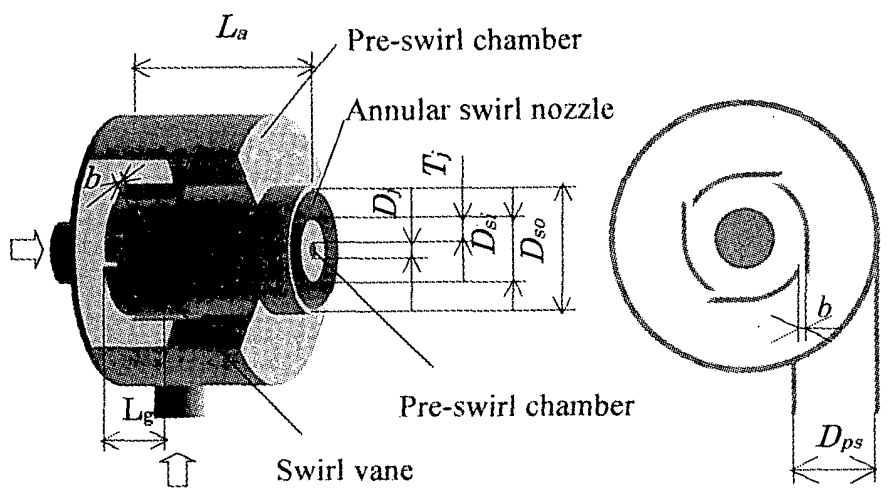

Fig.1 Compound swirl jet generator

日本機械学会講演論文集 N 0.048-1 ‘’ $04-3-19$, 九州支部第 57 期総会講演会] 


\section{3、実秧結果および势察}

Fig.2 は, 自由噴流管内径 $10 \mathrm{~mm}$ の複合旋回噴流 $Q_{s} / Q_{L}=$ 1.0 における $r-z$ 断面内の主流方向速度分布が下流方向 の変化を示している．また，比較のために以前の自由噴流 管内径 $4 \mathrm{~mm}$ の複合旋回噴流 $Q_{s} / Q_{s}=1.96$ における主流方向速 度分布を示す ${ }^{(6)}$

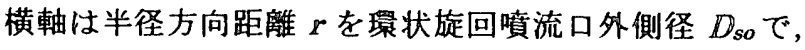
縦軸は主流方向速度 $U_{z}$ を队形自由噴流の主流方向最大速 度 Ujmax でそれぞれ無次元化してある。

自由噴流管内径 $4 \mathrm{~mm}$ の場合に比べ $10 \mathrm{~mm}$ の場合，主流方 向の速度减衰がかなり小さいことがわかる。これは，管径 の違いから自由噴流の発達域がより下流に遷移しているこ とによると考えられる。一般に噴流において，開口での平 均流速を $100 \%$ 保持している領域，ポテンシャルコアは吹 出し管直径の 2.5 倍程度とされているが，今回自由噴流管 内径を 2.5 倍まで拡大したことにより，ポテンシャルコア は以前より下流に 2.5 倍の位置まで伸びる。自由唄流管内 径 $4 \mathrm{~mm}$ の場合その位置が $z / D_{s o}=0.1$ であったのに㗅し，管 径 $10 \mathrm{~mm}$ の場合 $z / D_{s o}=0.25$ の位置まで達することになる. このことから, 自由噴流管内径 $4 \mathrm{~mm}$ の場合, 噴流吹出し 口近傍において環状旋回噴流のエントレインメントの影響 を強く受け，急速に速度が減衰したのに対し，今回の管径 $10 \mathrm{~mm}$ の場合，以前と比べ吹出しのエネルギーを保たれ噴 流抎散が抑えられていると考える。また，自由噴流管内径 $10 \mathrm{~mm}$ の場合 $4 \mathrm{~mm}$ に比べその速度分布は噴流中心朝よりに 分布しているが，これも同様に，吹出し口近傍での環状旋 回噴流のエントレインメントによる噴流拡散が㧕えられた ため,より強く環状旋回噴流を巻き込み下流まで噴流拡散 が抑えられたものと考えられる。これらのことから，自由 噴流管径を大きくしたことで, 自由噴流が主体的な流れに なっていると予想できる。

Fig.3に各断面の流量 $Q$ を平均速度の測定結果より算出 した結果を示す. 横軸は, 管出口端からの距㒕 $z$ を水力相 当直径 $D_{m}$ で, 繸軸は, 各坼面の流量 Q 管出口端での流 量 Qoでそれぞれ無次元化してある。

自由噴流管内径 $10 \mathrm{~mm}$ の複合旋回噴流は, 以前の管径 4 $\mathrm{mm}$ の場合と比較し, 全体的に流量增加率が小さい, 全体 の流量増加率の増加傾向は以前とほほ変わらないが, しか し自由噴流が主体のためか，下流において増加率の減衰が 小さい。これにより，下流において增加率の差が小さくな っている.このことから噴流全体の周囲流体の巻き込み量 としては, 以前の自由噴流管内径 $4 \mathrm{~mm}$ の場合と比べてそ の差はさほど大きくない.

また, 従来からプッシュ気流に用いられてきた自由噴流 と比皎した場合，各断面とも高い増加率を示す。このこと から自由噴流管内径 $10 \mathrm{~mm}$ の複合旋回噴流においても, フ ッシュプル型換気装置のプッシュ気流として用いることで, 従来の自由噴流を用いた場合に比べ，その高い巻き込み力 からより効果的な污染物質の補足及び排気が可能となる。

\section{4. 結論}

環状旋回噴流と同軸上の厚肉リムを有する円形自由噴流と で構成される複合旋回噴流の自由噴流管径を $4 \mathrm{~mm}$ から $10 \mathrm{~mm}$ と大きくしたことによる流れ特性の変化を明らかと した. その際，スワール数 1.50 の環状旋回噴流と円形自由 噴流の流量比 $Q_{S} / Q_{j}=1.0$ として，スモーク法による流れの 可視化実験および 5 孔球形ピトー管による 3 次元速度分布

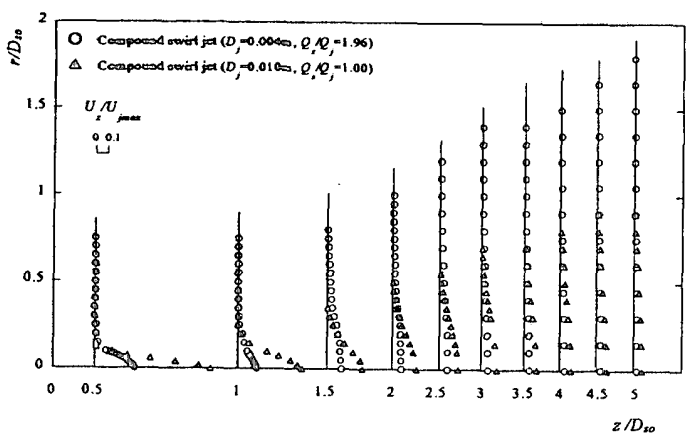

Fig.2 Arrial velocity distribution

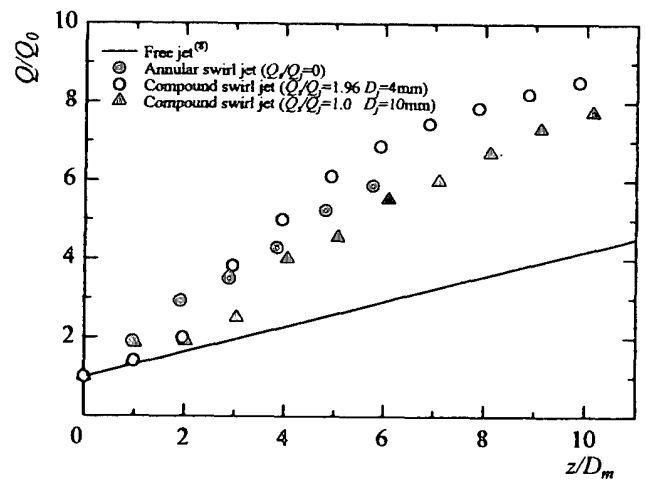

IFig.3 Increase of flow rate

測定を行った結果，次のような結論を得た。

自由噴流管内径 $10 \mathrm{~mm}$ の複合旋回噴流は，下流まで噴流 半径の拡散が抑制される。また，管径 $4 \mathrm{~mm}$ に比べ流量増 加率は低いが, 自由噴流と比べ十分な巻き込み量が得られ る.

以上のことから, 複合旋回噴流は自由噴流管内径を $10 \mathrm{~mm}$ と比較的大きくしても, 噴流半径の拡散が少なく, かつ周 囲流体の巻き込み効果も大きい流れを創生することができ る

よって，自由噴流側の空気源コンプレッサ一を送風機で 代替することは可能であることが分かった。これにより， プッシュプル型換気装置のプッシュ気流に複合旋回噴流を 用いたシステムにおいて，すべての空気源を一つのブロア

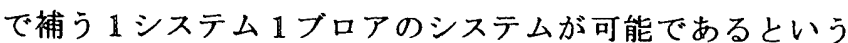
実用上有用な知見を得ることができた。

\section{参考文献}

（1)林，「換気・集じんシステム」，(1973), p. 188, 朝倉書店.

(2)林, 工場換気, (1982), p. 6, 空気調和・衛生工学会.

（3)野崎, 他 5 名, 可視化情報, Vol.18,Suppl.No.1(1998), pp. 41-44.

（4）野崎，他 5 名，可視化情報，Vol.20,Suppl.No.1(2000), pp. 477-480.

(5) Nozaki,T.,et al., Journal of Visualization, vol.6 No.2 (2003)

(7) Nozaki,T.,et al., The 4th ASME/JSME Joint Fluid Engineering Conference, HonoluluHawaii(2003), CD-ROM, FEDSM2003-45225

（7)須藤，他 2 名, B), vol.63No609, pp 132-139.

(8) Rajaratnam, N.,Turbulent jets, Elsevier, pp35-48(1976) 